\title{
Fluoride Concentration in the Top-Selling Brazilian Toothpastes Purchased at Different Regions
}

\author{
Antônio Pedro RICOMINI FILHO \\ Livia Maria Andaló TENUTA \\ Frederico Silva de Freitas FERNANDES \\ Ana Flávia Bissoto CALVO \\ Sandro Carvalho KUSANO \\ Jaime Aparecido CURY
}

Piracicaba Dental School, UNICAMP - University of Campinas, Piracicaba, SP, Brazil

\begin{abstract}
To be relevant in terms of public health, widely-used toothpastes should have at least 1,000 ppm of soluble fluoride (F) concentration. Thus, the concentrations of total fluoride (TF) and total soluble fluoride (TSF) in the top-selling Brazilian toothpastes were evaluated. Samples (n=3) from toothpastes Colgate Anti-cáries ${ }^{\circledR}$, Colgate Total 12 Clean Mint ${ }^{\circledR}$, Colgate Tripla Ação Menta Original ${ }^{\circledR}$, Colgate Tripla Ação Menta Suave ${ }^{\circledR}$ and Sorriso Dentes Brancos ${ }^{\circledR}$ were obtained from each of the five regions of the country. The concentrations of TF and TSF were analyzed with ion-specific electrode calibrated with F standards and the results were expressed in ppm ( $\mu \mathrm{g} \mathrm{F/g).}$ All toothpastes showed TF concentration lower than 1,500 ppm F (1,388.2 \pm 25.8 to $1,483.2 \pm 98.2)$. The TSF values were higher than $1,000 \mathrm{ppm} F$ and ranged from $1,035.5 \pm 61.5$ to $1,221.8 \pm 35.2$ for calcium carbonate/monofluorophosphate-based toothpastes and from $1,455.6 \pm 12.5$ to $1,543.0 \pm 147.3$ for silica/sodium fluoride-based toothpaste. Top-selling Brazilian toothpastes presented available fluoride concentration to control caries regardless of the region where they are purchased.
\end{abstract}

Key Words: toothpaste, fluoride, dental caries.

\section{INTRODUCTION}

Fluoride (F) toothpastes have been considered the main reason for the worldwide caries decline observed in the last decades $(1,2)$. The rationale for its use is based on the disruption of dental plaque by brushing, at the same time that $\mathrm{F}$ is released to the oral environment (3, 4). However, to be anticaries effective, the toothpaste formulation must provide soluble $\mathrm{F}$, either as fluoride ion or as monofluorophospate (MFP) ion, to the oral cavity, to interfere with the caries process reducing enamel-dentine demineralization and enhancing the remineralization (3-7).

In Brazil, $90 \%$ of the population use calcium carbonate/MFP-based $\left(\mathrm{CaCO}_{3} / \mathrm{MFP}\right)$ toothpastes (2). Although MFP ion does not form insoluble salt with calcium ions $\left(\mathrm{Ca}^{++}\right)$from the abrasive, MFP is not stable and during toothpaste storage it is hydrolyzed releasing $\mathrm{F}$ ion that reacts with $\mathrm{Ca}^{++}$forming insoluble $\mathrm{F}$ salts, which would be caries inactive. At least 1,000 ppm of soluble $\mathrm{F}$ is considered necessary for a toothpaste to have anticaries effect (8), but the current Brazilian legislation only sets the maximum $\mathrm{F}$ concentration at $1,500 \mathrm{ppm} \mathrm{F}$, without mentioning the need of soluble, anticaries active $F(9)$. While the quality of $F$ found in Brazilian toothpastes has been followed since 1981 (2), recent analysis of toothpastes used by children showed that $36 \%$ of $\mathrm{CaCO}_{3} / \mathrm{MFP}$ toothpastes formulated with $1,100 \mathrm{ppm} F$ or more had less than $1,000 \mathrm{ppm}$ of soluble $\mathrm{F}(10)$. This raises concerns on the soluble $\mathrm{F}$ availability in the top-selling Brazilian F toothpastes because the caries decline observed in Brazil after the 1990' has been explained by the widespread availability of $F$ toothpaste in the market (2).

Moreover, considering that the hydrolysis of MFP is heat-accelerated $(11,12)$ and the clime in Brazil ranges from subtropical to tropical, respectively in the south-southeast and midwest-north-northeast regions, the amount of soluble $\mathrm{F}$ in toothpastes sold at the different Brazilian regions could be different. Also, 
most Brazilian toothpastes are manufactured in the São Paulo state, in the southeast region of the country, and they are transported to the other regions by road. Therefore, Brazilian people living in different regions could receive different anticaries benefits using the same brand of toothpaste.

Thus, the concentrations of total fluoride (TF) and total soluble fluoride (TSF) in the top-selling Brazilian toothpastes purchased from the five country regions was evaluated in this study.

\section{MATERIAL AND METHODS}

\section{Study Design}

An analytical study was carried out in order to evaluate the TF and TSF concentrations in the five top-selling Brazilian toothpastes. Information about the toothpastes analyzed in the study is given in Table 1. The toothpastes $(n=3)$ were purchased in three different supermarkets in one city of each of the five country regions: Manaus, State of Amazonas, north (N) region; Fortaleza, State of Ceará, northeast (NE) region; Cuiabá, State of Mato Grosso do Sul, midwest (MW) region; Piracicaba, State of São Paulo, southeast (SE) region; and Pelotas, State of Rio Grande do Sul, south (S) region. All analyses were performed in duplicate using an ion specific electrode (Orion 96-09; Orion Research, Cambridge, MA, USA).

\section{Determination of Fluoride Concentration}

Fluoride concentration in the toothpastes was determined as previously described (10). Briefly, an amount of 90 to $110 \mathrm{mg}$ of toothpaste was weighed $( \pm 0.01 \mathrm{mg}$ ), homogenized in $10.0 \mathrm{~mL}$ of deionized water and duplicates of $0.25 \mathrm{~mL}$ of the suspension were transferred to assay tubes for TF analysis (sum of soluble and insoluble fluoride). The remaining of the suspension was centrifuged $(3,000 \mathrm{~g}, 10 \mathrm{~min}$, room temperature) to remove insoluble fluoride, bound to the abrasive. Duplicates of $0.25 \mathrm{~mL}$ of the supernatant were transferred to assay tubes to determine TSF concentration (sum of $F$ as $\mathrm{F}$ ion and MFP ion). For all TF and TSF tubes, 0.25 $\mathrm{mL}$ of $2.0 \mathrm{M} \mathrm{HCl}$ was added, and after $1 \mathrm{~h}$ at $45^{\circ} \mathrm{C}$, the samples were neutralized with $0.5 \mathrm{~mL}$ of $1.0 \mathrm{M} \mathrm{NaOH}$ and buffered with $1.0 \mathrm{~mL}$ of TISAB II (1.0 M acetate buffer, pH 5.0, containing $1.0 \mathrm{M} \mathrm{NaCl}$ and $0.4 \%$ CDTA). The analyses were carried out using an ion-specific electrode (Orion 96-09) coupled to an ion analyzer (Orion EA-740; Orion Research), previously calibrated with F standards (final $\mathrm{F}$ concentration of $0.0625,0.125,0.25,0.5,1.0$, 2.0 and $4.0 \mathrm{ppm} \mathrm{F}$ ) prepared as the samples.

For each analysis, a linear equation correlating the logarithm of $\mathrm{F}$ concentration in standards and $\mathrm{mV}$ was calculated $\left(r^{2}>0.999\right)$ using the software EXCEL (Microsoft) and used to determine the F concentration in each toothpaste, which was expressed as ppm ( $\mu \mathrm{g}$ $\mathrm{F} / \mathrm{g}$ ). The slopes of the linear regressions ranged from -57.7 to -56.7 . All the analyses were above the detection limit of the standard curve used $(0.0625 \mathrm{ppm} \mathrm{F})$ and the $\mathrm{mV}$ values were in the linear region of the curve. The average variation coefficients of the repeated analyses (duplicate) were $1.3 \% \pm 1.2$.

\section{Statistical Analysis}

The average and standard deviation values of F concentration of each toothpaste brand purchased at the different regions were calculated using Microsoft Excel. The effect of the region where the toothpaste was purchased was tested using one-way ANOVA.

Table 1. Information about the toothpastes analyzed in the study.

\begin{tabular}{|c|c|c|c|c|}
\hline Commercial brand* & $\begin{array}{l}\text { Code for } \\
\text { analysis }\end{array}$ & $\begin{array}{c}\text { Fluoridated } \\
\text { agent declared }\end{array}$ & $\begin{array}{l}\text { Fluoride concentration } \\
\text { declared }(\mathrm{ppm} \mathrm{F})\end{array}$ & $\begin{array}{l}\text { Abrasive agent } \\
\text { declared }\end{array}$ \\
\hline Colgate Máxima Proteção Anti-cáries ${ }^{\circledR}$ & A & MFP & 1,450 & Calcium carbonate \\
\hline Colgate Total 12 Clean Mint ${ }^{\circledR}$ & $\mathrm{B}$ & $\mathrm{NaF}$ & 1,450 & Silica \\
\hline Colgate Tripla Ação Menta Original ${ }^{\circledR}$ & $\mathrm{C}$ & MFP & 1,450 & Calcium carbonate \\
\hline Colgate Tripla Ação Menta Suave ${ }^{\circledR}$ & $\mathrm{D}$ & MFP & 1,450 & Calcium carbonate \\
\hline Sorriso Dentes Brancos ${ }^{\circledR}$ & $\mathrm{E}$ & MFP & 1,450 & Calcium carbonate \\
\hline
\end{tabular}

*Top-selling Brazilian toothpastes (confidential information). All toothpastes were within the expiration date. MFP $=$ sodium monofluorophosphate, $\mathrm{NaF}=$ sodium fluoride. 
The assumptions of equality of variances and normal distribution of errors were previously checked and were satisfied. The SAS software (SAS Institute Inc., version 9.0, Cary, NC, USA) was used for the statistical analysis, with a significance level fixed at $5 \%$.

\section{RESULTS}

TF concentrations (Fig. 1) were very close to the expected amount of $1,450 \mathrm{ppm}$ stated in the manufacturer's packaging (Table 1). The disagreement between the concentration declared and that found ranged from $-4.3 \%$ to $2.3 \%$. In addition, all concentrations were in accordance with the Brazilian law, presenting a TF concentration not higher than $1,500 \mathrm{ppm}$. No significant difference $(\mathrm{p}>0.05)$ was observed for TF concentration in each toothpaste among the five regions evaluated.

TSF concentrations ranged from $1,035.5 \pm 61.5$ to $1,221.8 \pm 35.2$ for MFP-based toothpastes and from $1,455.6 \pm 12.5$ to $1,543.0 \pm 147.3$ for the NaF-based toothpaste (Fig. 2). There was no significant difference $(p>0.05)$ for TSF concentration for each toothpaste among the five regions.

\section{DISCUSSION}

All the five top-selling Brazilian toothpastes are formulated with 1,450 ppm F, but in four of them the salt used is MFP and in one is NaF (Table 1). This TF concentration declared in the label of the toothpastes

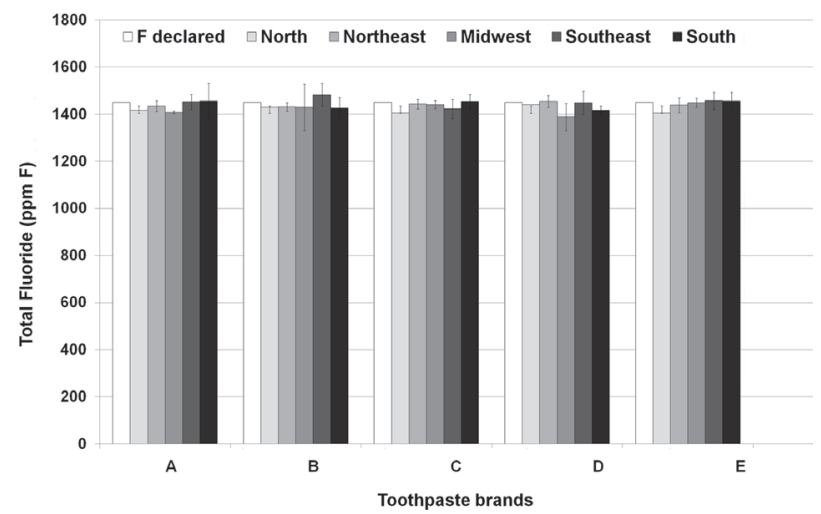

Figure 1. Concentration (ppm F) of total fluoride (TF) declared by the manufacturer and found in the toothpastes purchased at the Brazilian regions (mean $\pm \mathrm{SD}, \mathrm{n}=3$ ). No significant difference among the Brazilian regions for each toothpaste was found ( $p>0.05$ ). (A) Colgate Máxima Proteção Anti-cáries ${ }^{\circledR}$, (B) Colgate Total 12 Clean Mint ${ }^{\circledR},(C)$ Colgate Tripla Ação Menta Original ${ }^{\mathbb{Q}},(\mathrm{D})$ Colgate Tripla Ação Menta Suave ${ }^{\circledR}$ and (E) Sorriso Dentes Brancos ${ }^{\circledR}$.
(Fig. 1) is in accordance with the Brazilian and Mercosur legislations, which set $1,500 \mathrm{ppm} \mathrm{F}$ as the maximum value (9).

According to the label, the abrasive agent of the toothpaste containing $\mathrm{NaF}$ is silica (Table 1), which assures that all fluoride is soluble, and indeed our analyses confirmed that the $1,450 \mathrm{ppm} F$ of this toothpaste are soluble (Fig. 2), irrespective of the Brazilian region where it was purchased. However, the abrasive of the other toothpastes is $\mathrm{CaCO}_{3}$ (Table 1) and it is possible that part of the $\mathrm{F}$ is inactive as insoluble salts $(2,10,11)$. This fact is relevant because these four toothpastes containing $\mathrm{MFP} / \mathrm{CaCO}_{3}$ are among the five most consumed in Brazil.

The present results showed that the TSF concentration in the fresh samples of toothpastes containing $\mathrm{MFP} / \mathrm{CaCO}_{3}$ was $21 \%$ lower (Figs. 1 and 2) than the TF declared in the label and found in the analyses (Fig. 1). However, in all toothpastes analyzed the TSF concentrations were higher than $1,000 \mathrm{ppm} \mathrm{F}$, the minimum necessary to have anticaries effect (8).

Furthermore, the TSF concentration present in toothpastes containing $\mathrm{MFP} / \mathrm{CaCO}_{3}$ was not different among the five country regions (Fig. 2). This result could be explained by the fact that these toothpastes were purchased in large supermarkets, which have temperature control. Also, the lack of difference in TSF in toothpastes bought in the Southeast region of Brazil, where they are manufactured, and those bought in hotter regions, suggests that the conditions of transportation or



Figure 2. Concentration (ppm F) of total soluble fluoride (TSF) in the toothpastes purchased at the Brazilian regions (mean $\pm \mathrm{SD}$, $\mathrm{n}=3$ ). No significant difference among the Brazilian regions for each toothpaste was found ( $p>0.05$ ). (A) Colgate Máxima Proteção Anti-cáries $^{\circledR},(\mathrm{B})$ Colgate Total 12 Clean Mint $^{\circledR},(\mathrm{C})$ Colgate Tripla Ação Menta Original ${ }^{\circledR}$, (D) Colgate Tripla Ação Menta Suave ${ }^{\circledR}$ and (E) Sorriso Dentes Brancos ${ }^{\circledR}$. 
storage in distributors before arriving at the sale store are not responsible for the MFP hydrolysis and the 21\% of insoluble $\mathrm{F}$ found.

Although the calcium carbonate-based toothpastes presented a lower amount of soluble F than the silicabased toothpaste, all of them showed TSF concentration higher than 1,000 ppm $\mathrm{F}$, which is the minimum necessary for anticaries effect (8). Thus, the difference between the anticaries effect of top-selling Brazilian toothpastes, either $\mathrm{NaF} /$ silica or MFP/calcium carbonatebased, can be regarded as irrelevant. This agrees with the caries decline observed in the country in the last decades (2), which occurred countrywide irrespective of fluoridated water availability.

In conclusion, the top-selling Brazilian toothpastes are in accordance with the Brazilian law and they present available fluoride concentration to control caries, regardless of the region where they are purchased.

\section{ACKNOWLEDGEMENTS}

The technical support of Mr. Waldomiro Vieira Filho is greatly acknowledged. We thank Adelsilene Veras, Gisele Moi, Renata Barbosa and Vanara Passos for the help with the purchase of the toothpastes at the different Brazilian regions. This study was conducted as an activity of the discipline "In vitro models in Cariology" of the Graduate Program in Dentistry, Cariology Area, Piracicaba Dental School, UNICAMP.

\section{RESUMO}

Para ter relevância em termos de saúde pública, os cremes dentais amplamente utilizados pela população devem ter fluoreto $(\mathrm{F})$ solúvel numa concentração mínima de 1.000 ppm F. Assim, as concentrações de fluoreto total (FT) e flureto solúvel total (FST) nos cremes dentais mais vendidos no Brasil foram avaliados. Os cremes dentais $(n=3)$ Colgate Anti-cáries ${ }^{\circledR}$, Colgate Total 12 Clean Mint ${ }^{\circledR}$, Colgate Tripla Ação Menta Original ${ }^{\circledR}$, Colgate Tripla Ação Menta Suave ${ }^{\circledR}$ e Sorriso Dentes Brancos ${ }^{\circledR}$ foram obtidos nas cinco regiões do país. As concentrações de FT e FST foram analisadas com eletrodo íon-específico calibrado com padrões de $\mathrm{F}$ e os resultados foram expressos em ppm ( $\mu \mathrm{g} \mathrm{F} / \mathrm{g}$ ). Todos os cremes dentais apresentaram concentração de FT inferior a 1.500 ppm F $(1.388,2 \pm 25,8$ a $1.483,2 \pm 98,2)$. Os valores de FST foram superiores a $1.000 \mathrm{ppm} F$ e variaram de 1.035,5 $\pm 61,5 \mathrm{a}$ $1.221,8 \pm 35,2$ para cremes dentais a base de carbonato de cálcio/ monofluorfosfato e de $1.455,6 \pm 12,5$ a $1.543,0 \pm 147,3$ para o creme dental à base de sílica/fluoreto de sódio. Os cremes dentais mais vendidos no Brasil apresentaram concentração de fluoreto solúvel para controlar cárie, independentemente da região onde foram comprados.

\section{REFERENCES}

1. Bratthall D, Hansel-Petersson G, Sundberg H. Reasons for the caries decline: what do the experts believe? Eur J Oral Sci 1996;104:416-422.

2. Cury JA, Tenuta LM, Ribeiro CC, Paes Leme AF. The importance of fluoride dentifrices to the current dental caries prevalence in Brazil. Braz Dent J 2004;15:167-174.

3. Cury JA, Tenuta LMA. How to maintain a cariostatic fluoride concentration in the oral environment. Adv Dent Res 2008;20:1316.

4. Tenuta LM, Zamataro CB, Del Bel Cury AA, Tabchoury CP, Cury JA. Mechanism of fluoride dentifrice effect on enamel demineralization. Caries Res 2009;43:278-285.

5. Tenuta LM, Cury JA. Fluoride: its role in dentistry. Braz Oral Res 2010;24:9-17.

6. ten Cate JM. In vitro studies on the effects of fluoride on de- and remineralization. J Dent Res 1990;69:614-619.

7. Queiroz CS, Hara AT, Paes Leme AF, Cury JA. pH-cycling models to evaluate the effect of low fluoride dentifrice on enamel de- and remineralization. Braz Dent J 2008;19:21-27.

8. Walsh T, Worthington HV, Glenny AM, Appelbe P, Marinho VC, Shi X. Fluoride toothpastes of different concentrations for preventing dental caries in children and adolescents. Cochrane Database Syst Rev 2010;CD007868.

9. Brazil, National Health Surveillance Agency (ANVISA) Resolution 79, August 28, 2000 (in Portuguese).

10. Cury JA, Oliveira MJL, Martins CC, Tenuta LM, Paiva SM. Available fluoride in toothpastes used by Brazilian children. Braz Dent J 2010;21:396-400.

11. Conde NC, Rebelo MA, Cury JA. Evaluation of the fluoride stability of dentifrices sold in Manaus, AM, Brazil. Braz Oral Res 2003; 17:247-253.

12. Tabchoury CPM, Cury JA. Accelerated aging of dentifrices to predict fluoride stability under normal conditions. [Original in Portuguese]. Rev Bras Farm 1994;75:67-71.

Received August 19, 2011 Accepted November 28, 2011 